UDC: $575.86+578.832 .1$

\title{
Phylogenetic analysis of influenza A viruses (H1N1)pdm circulating during 2014-2015 epidemic season in Ukraine
}

\author{
L. V. Radchenko ${ }^{1}$, O. Yu. Smutko ${ }^{1,2}$, A. Yu. Fesenko ${ }^{1}$, A. P. Mironenko ${ }^{1}$ \\ ${ }^{1}$ Gromashevsky L. V. Institute of Epidemiology and Infection Diseases, NAMS of Ukraine \\ 5, Amosova Str., Kyiv, Ukraine, 03038 \\ 2 Educational and Scientific Center "Institute of Biology", Taras Shevchenko National University of Kyiv \\ 64/13, Volodymyrska Str., Kyiv, Ukraine, 01601 \\ larysa_rad@ukr.net
}

\begin{abstract}
Aim. To analyze the pandemic influenza A(H1N1) strains that circulated in Ukraine during 2014-2015 epidemic season. Methods. Real-time polymerase chain reaction (RT-PCR). The phylogenetic trees were constructed using MEGA 6 software. Results. The strains, that were circulating in Ukraine were similar to those of the A/California/07/2009 (H1N1) vaccine strain. Most strains belonged to the clade 6B. The H275Y mutation in the neuraminidase (NA) gene was identified, that confers resistance to oseltamivir. Conclusions. Based on the nucleotide sequences of HA and NA genes, we constructed the influenza virus phylogenetic trees. The influenza virus isolated in 2014-2015 epidemic season had a specific mutation, associated with resistance to antiviral drugs such as oseltamivir.
\end{abstract}

Ke y w or d s: A(H1N1)pdm influenza viruses, mutation, phylogenetic analysis, isolate.

\section{Introduction}

The influenza A(H1N1)pdm2009 (H1N1/2009) virus that emerged in humans during March and early April 2009 spread rapidly among humans to develop into the first human influenza pandemic in over 40 years [1]. The introduction of a new virus with increased transmissibility into a population makes it necessary the surveillance of the pandemic strain at the molecular level [2].

The phylogenetic analysis applied to the influenza isolates allows monitoring the rate and intensity of virus variations practically in real time. Furthermore, the comparative analysis of their protein sequences allows revealing the point amino acid substitution providing the mechanism of virus adaptation to human immune system and resistance to antiviral drugs [3].

\section{Materials and Methods}

Nasal-throat swabs were taken from the patients with suspected influenza and SARI (severe acute respiratory infections). Diagnosis of H1N1pdm infection was carried out for all samples by the real-time polymerase chain reaction (RT-PCR) [4]. The influenza viruses $\mathrm{A}(\mathrm{H} 1 \mathrm{~N} 1)$ pdm were isolated in MDCK cell culture [5]. The isolates were later used for the strain identification and sequencing.

The sequencing of influenza viruses isolates was performed in the World Influenza Center in London using the technology of RNA-SEQ, which allows the sequencing of coding and noncoding mRNA. The sequences of influenza viruses from other countries were received from web-site GISAID (the Global Initiative on Sharing All Influenza Data $\mathrm{http} / / /$ platform.gisaid.org) using BLAST analysis.

C 2016 L. V. Radchenko et al.; Published by the Institute of Molecular Biology and Genetics, NAS of Ukraine on behalf of Biopolymers and Cell.

This is an Open Access article distributed under the terms of the Creative Commons Attribution License (http://creativecommons.org/licenses/by/4.0/),

which permits unrestricted reuse, distribution, and reproduction in any medium, provided the original work is properly cited 
The sequences were aligned using ClustalW algorithm. The phylogenetic trees were built by the neighbor joining method [6] applying the Kimura 2-parameter model [7]. A bootstrap technique with 1000 replications was used to test statistical validity of received data [8]. Nucleotide sequences were translated into amino acid sequences using MEGA 6 software [9].

\section{Results and Discussion}

In this study we compared the nucleotide sequences of influenza viruses HA and NA proteins.

\section{Comparison of hemagglutinin (HA) genes}

The genetic comparison of the influenza virus $\mathrm{A}(\mathrm{H} 1 \mathrm{~N} 1) \mathrm{pdm}$ hemagglutinin genes showed that all investigated isolates were genetically related to the reference strain A/South Africa/3626/2013 and saved high (96\%) genetic similarity to vaccines strain A/California/07/2009.

The majority of the viruses isolated recently match with the genetic group 6. This group is further subdivided into subgroups $6 \mathrm{~A}, 6 \mathrm{~B}$ and $6 \mathrm{C}$. Ukrainian isolates belong to group $6 \mathrm{~B}$.

Phylogenetic data are presented in Fig.1.

All discovered isolates selected substitutions P83S and I321V, except vaccine strainA/California/07/2009, also S203T - without A/Bayern/69/2009.

All Ukrainian isolates were substitutions E347K, $\mathrm{S} 451 \mathrm{~N}$ and S185T. The 6B group was indicated by existence of substitutions K163Q, K283E, and E499K in HA1 (e.g. A/South Africa/3626/2013), significant part of viruses also contained - V321I and A256T, which were detected in 2012-2013 and 2013-2014 seasons. The A/Dnipro /454/2015 isolate contained substitution D94N (aspartic acid is replaced by asparagines) and was the closest to isolate from Belgium. The A/Ukraine/433/2015 was the most related to the strains from Slovenia and was selected substitutions R205K (arginine is replaced by lysine) and S84N (serine is replaced by asparagines). Influenza viruses circulated in 2014-2015 epidemic season had no mutation D222G, associated with severe disease [10].

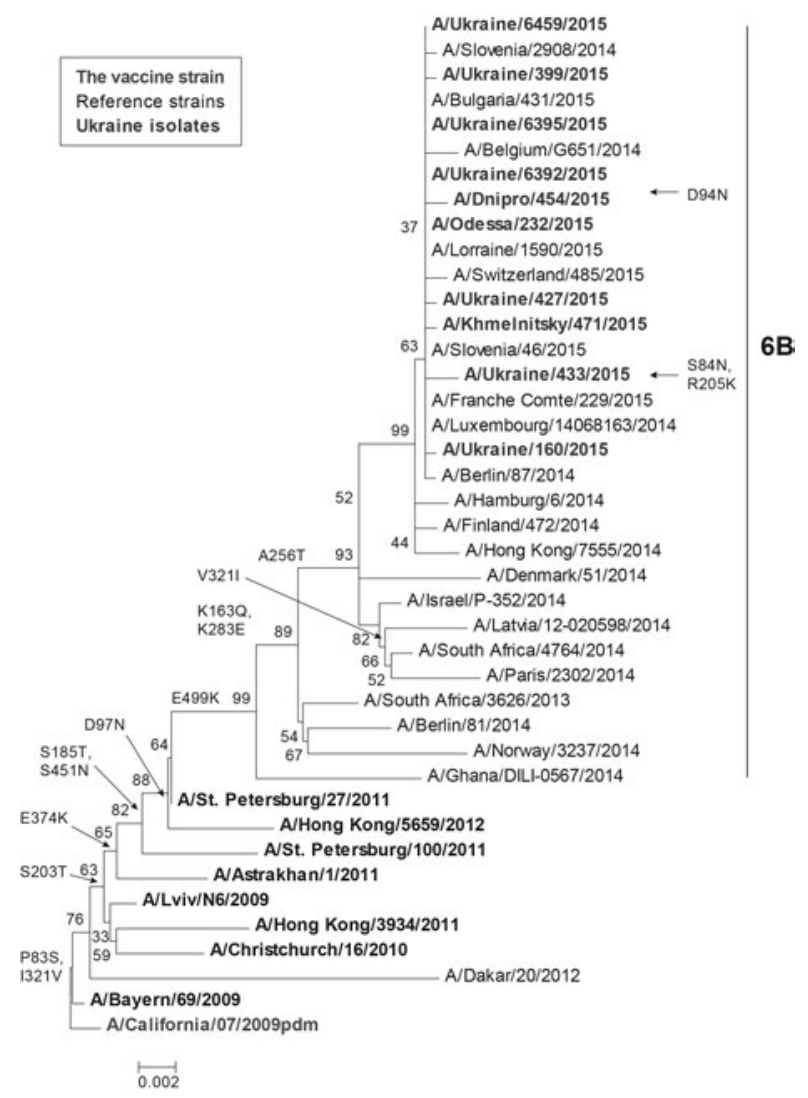

Fig. 1. Phylogenetic analysis of the HA gene of influenza A(H1N1)pdm viruses isolated during 2014-2015 epidemic season

\section{Comparison of neuraminidase (NA) genes}

Genetic comparison of influenza virus A(H1N1)pdm neuraminidase genes showed that all investigated isolates were genetically related to the reference strain A/ South Africa/3626/2013 and saved high genetic similarity to the vaccines strain A/California/07/2009.

The phylogenetic data are presented in Fig.2.

All discovered isolates were distinguished substitution N248D compared with the A/California/07/2009, except the A/Bayern/69/2009 strain. The substitution V106I identified in 2009 reverted to the wild type I106V in 2014-2015 epidemic season. Most viruses were selected substitutions V241I, N369K and a group of isolates contained the Ukrainian gain I34V, N44S, N200S substitutions.

The influenza viruses $\mathrm{A}(\mathrm{H} 1 \mathrm{~N} 1)$ pdm isolated during 2013-2014 season were distinguished substitu- 


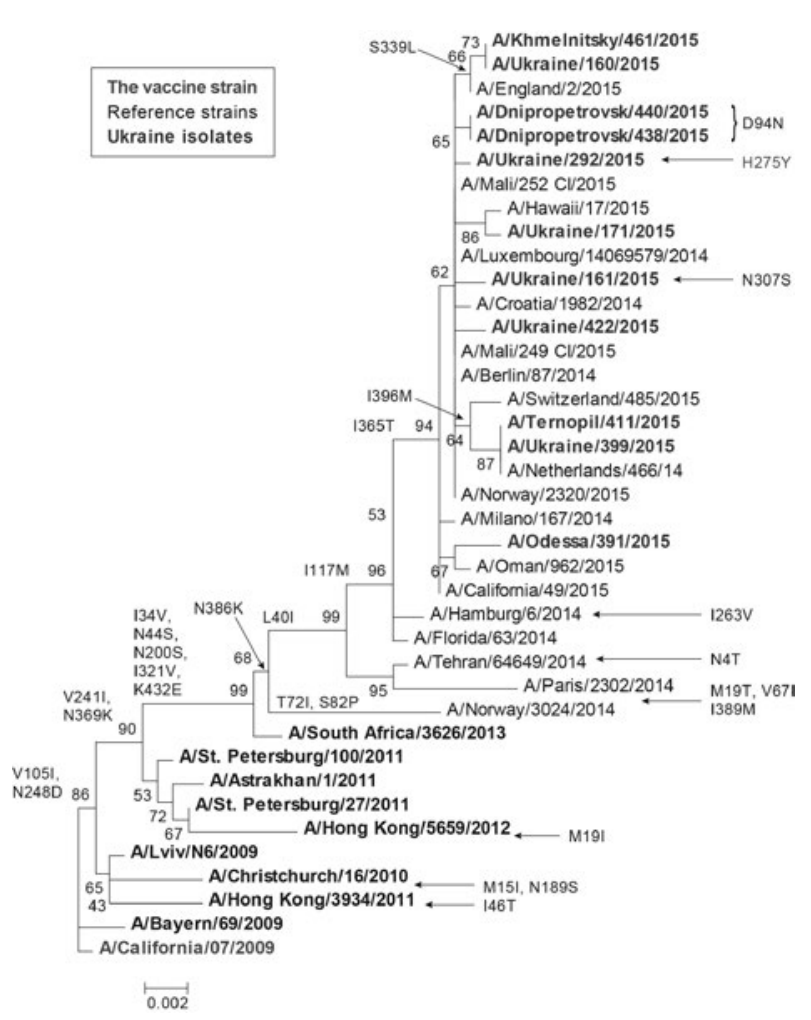

Fig. 2. Phylogenetic analysis of the NA gene of influenza A(H1N1)pdm viruses isolated during 2014-2015 epidemic season

tions I34V, I321V and K432E, which attended 20132014 season, but were absent in 2012-2013 season. All Ukrainian isolates were selected substitutions I117M and I365M. Two isolates A/Ternopil/411/2015 and A/Ukraine/399/2015 were indicated by existence of substitution I396M (isoleucine is replaced by methionine), which were the closest to isolates from Switzerland and Netherlands. Another unique substitution had the A/Ukraine/161/2015 isolate - N307S. Two viruses from Dnipropetrovsk were selected substitution $\mathrm{P} 272 \mathrm{H}$ (proline is replaced by histidine). The isolates A/Ukraine/160/2015 together with A/ Khmelnitsky/461/2015 and A/England/02/2015 received amino acid substitution S339L .

The resistant viruses possessed an $\mathrm{H} 275 \mathrm{Y}$ [11] substitution in the NA protein. The H275Y substitution or other known substitutions associated with the reduced susceptibility to NA inhibitors were observed in one isolate from Kiev -A/Ukraine/292/2015.

\section{Conclusions}

Etiological structure of influenza viruses in Ukraine was different from neighboring countries and European region, where viruses $\mathrm{A}(\mathrm{H} 3 \mathrm{~N} 2)$ were dominant. Influenza viruses $\mathrm{B} /$ Yamagata were predominant in Ukraine. The activity of influenza viruses type A(H1N1) pdm09 and $A(N 3 N 2)$ was significantly lower than type B in Ukraine during 2014-2015 epidemic season. Etiologic process was of moderate severity.

The influenza viruses type $\mathrm{A}(\mathrm{H} 1 \mathrm{~N} 1)$ pdm isolated in Ukraine during 2014-2015 located in group 6B and their hemagglutinin and neuraminidase genes almost did not change. The genetic comparison of the influenza virus $\mathrm{A}(\mathrm{H} 1 \mathrm{~N} 1) \mathrm{pdm}$ genes showed that all investigated isolates were genetically related to the reference strain A/South Africa/3626/2013 and saved high genetic similarity to the vaccines strain A/Califor$\mathrm{nia} / 07 / 2009$. Among strains analyzed the H275Y mutation in the neuraminidase (NA) gene was identified, which confers resistance to oseltamivir.

\section{REFERENCES}

1. Ramos AP, Herrera BA, Ramírez OV, García AA, Jiménez MM, Valdés CS, Fernández AG, González G, Fernández SI, Báez GG, Espinosa BH. Molecular and phylogenetic analysis of influenza A H1N1 pandemic viruses in Cuba, May 2009 to August 2010. Int J Infect Dis. 2013;17(7):e565-7.

2. Barrero PR, Viegas M, Valinotto LE, Mistchenko AS. Genetic and phylogenetic analyses of influenza A H1N1pdm virus in Buenos Aires, Argentina. J Virol. 2011;85(2):1058-66.

3. Parida M, Dash PK, Kumar JS, Joshi G, Tandel K, Sharma S, Srivastava A, Agarwal A, Saha A, Saraswat S, Karothia $D$, Malviya $V$. Emergence of influenza A (H1N1)pdm09 genogroup 6B and drug resistant virus, India, January to May 2015. Euro Surveill. 2016;21(5):6-11.

4. World Health Organization (WHO). CDC protocol of realtime RT-PCR for infl uenza H1N1. World Health Orga ni zation, Geneva, Switzerland. 30 April 2009.

5. Oh DY, Barr IG, Mosse JA, Laurie KL. MDCK-SIAT1 cells show improved isolation rates for recent human influenza viruses compared to conventional MDCK cells. J Clin Microbiol. 2008;46(7):2189-94.

6. Saitou N, Nei M. The neighbor-joining method: a new method for reconstructing phylogenetic trees. Mol Biol Evol. 1987;4(4):406-25.

7. Kimura M. A simple method for estimating evolutionary rates of base substitutions through comparative studies of nucleotide sequences. J Mol Evol. 1980;16(2):111-20. 
8. Felsenstein J. Confidence limits on phylogenies: an approach using the bootstrap. Evolution. 1985;39(4):783-91.

9. Tamura K, Stecher G, Peterson D, Filipski A, Kumar S. MEGA6: Molecular Evolutionary Genetics Analysis version 6.0. Mol Biol Evol. 2013;30(12):2725-9.

10. Kilander A, Rykkvin R, Dudman SG, Hungnes O. Observed association between the HA1 mutation D222G in the 2009 pandemic influenza $\mathrm{A}(\mathrm{H} 1 \mathrm{~N} 1)$ virus and severe clinical outcome, Norway 2009-2010. Euro Surveill. 2010;15(9). pii: 19498.

11. Lackenby A, Hungnes O, Dudman SG, Meijer A, Paget WJ, Hay AJ, Zambon MC. Emergence of resistance to oseltamivir among influenza A(H1N1) viruses in Europe. Euro Surveill. 2008;13(5). pii: 8026.

\section{Філогенетичний аналіз вірусів грипу А (H1N1)pdm, епідемії 2014-2015 в Україні}

Л. В. Радченко, О. Ю. Смутько, А. Ю. Фесенко,

А. П. Міроненко

Мета. Молекулярний та філогенетичний аналіз пандемічних вірусів грипу A(H1N1), що циркулювали в Україні протягом сезону 2014-2015 років. Методи. Зразки були проаналізовані методом полімеразної ланцюгової реакції (ПЛР) в реальному часі. Філогенетичні дерева будували в програмі MEGA6. Результати. Сиквенси українських ізолятів вірусів грипу А(H1N1)pdm були подібними до вакцинного штаму A/California/07/2009. Більшість штамів належали до кладу 6В. Серед досліджуваних ізолятів виявили мутацію Н275Y в гені нейрамінідази, яка зумовлює стійкість до озельтамівіру. Висновки. Базуючись на сиквенсах генів НА i NA вірусів грипу побудували філогенетич- ні дерева. Український вірус, виділений в сезоні 2014-2015 років мав специфічну мутацію, яку асоціюють з стійкістю до противірусних препаратів, таких як озельтамівір.

К л юч о в і с л о в а: віруси грипу A(H1N1)pdm, мутація, філогенетичний аналіз, ізолят.

\section{Филогенетический анализ вирусов гриппа A (H1N1)pdm, эпидемии 2014-2015 в Украине}

Л. В. Радченко, О. Ю. Смутько, А. Ю. Фесенко, А. П. Мироненко

Цель. Молекулярный и филогенетический анализ пандемических вирусов гриппа A(H1N1), которые циркулировали в Украине на протяжении 2014-2015 годов. Методы. Образцы были проанализированы методом полимеразной цепной реакции (ПЦР) в реальном времени. Филогенетические деревья построили в программе MEGA 6. Результаты. Сиквенсы украинских изолятов вирусов гриппа A(H1N1)pdm были подобными к вакцинному штамму A/California/07/2009. Большинство штаммов принадлежали к клайду 6В. Среди исследованных изолятов обнаружили мутацию $\mathrm{H} 275$ Ү в гене нейраминидазы. Выводы. Основываясь на сиквенсах генов НА и NA вирусов гриппа, построили филогенетические деревья. Украинский вирус, изолированный в сезоне 2014-2015 годов имел специфическую мутацию, которую ассоциируют с устойчивостью к противовирусным препаратам, таким как осельтамивир.

Кл юч е в ы е с л о в а: вирусы гриппа A(H1N1)pdm, мутация, филогенетический анализ, изолят.

Received 29.02.2016 